\title{
KONTRIBUSI PRODUK SUSU TERHADAP ASUPAN KALSIUM PADA MAHASISWI
}

\author{
Contribution Dairy Products On Calcium Dietary Intake In Female \\ University Student
}

\author{
Triyanti, Wita Nurul Aini, Ratu Ayu Dewi Sartika \\ Departemen Gizi Fakultas Kesehatan Masyarakat, Universitas Indonesia \\ triyantigizi@gmail.com
}

\begin{abstract}
Calcium is one of important mineral for female student to obtain the peak bone mass.This study aims to find out the amount and adequacy of calcium intake, and the contribution of dairy products to calcium intake among female student. This study used a cross-sectional study design. A total 58 third and fourth level nutrition student were selected randomly as samples. Calcium intake is obtained by using semiquantitative FFQ that has been validated. The results of the study showed an average calcium intake was $630 \pm 395$ mg/day, with $417.8 \pm 367.7 \mathrm{mg}$ coming from dairy products.There was $13 \%$ student who obtained Requirement Daily Allowance for calcium.
\end{abstract}

Keywords: Calcium intake, Dairy products, Female student

\section{ABSTRAK}

Kalsium merupakan mineral yang sangat dibutuhkan oleh mahasiswi untuk mencapai puncak masa tulang (peak bone mass). Penelitian bertujuan mengetahui jumlah dan kecukupan asupan kalsium serta kontribusi produk susu terhadap asupan kalsium pada mahasiswi. Penelitian menggunakan data sekunder dengan desain studi cross-sectional. Sejumlah 58 mahasiswi terpilih secara random sebagai sampel. Asupan kalsium didapatkan dengan menggunakan semiquantitative $F F Q$ yang sudah divalidasi. Hasil penelitian menunjukkan rerata asupan kalsium sebesar $630 \pm 395 \mathrm{mg} / \mathrm{hari}$, dengan $417.8 \pm 367.7 \mathrm{mg} / \mathrm{hari}$ berasal dari produk susu. Sejumlah $13 \%$ mahasiswi mencapai Angka Kecukupan Gizi untuk kalsium.

Kata Kunci : Asupan kalsium, Produk susu, Mahasiswi

\section{PENDAHULUAN}

Mahasiswi pada umumnya berusia 18-24 tahun, merupakan masa peralihan antara remaja menjadi dewasa muda. Pada masa ini masih terjadi proses pertumbuhan tulang terutama tulang panggul yang terkait dengan proses reproduksi. Pada masa ini juga terjadi proses pembentukan masa tulang dan kekerasan tulang hingga mencapai puncaknya (peak bone mass) (Lesli, 1999). Peak bone mass yang rendah menyebabkan masalah osteoporosis sehingga tulang mudah patah (Ford, 2007). Kejadian osteoporosis dan patah tulang lebih banyak dialami oleh perempuan terutama bila telah menopause (Ueno, 2005). Salah satu mineral penting yang dibutuhkan untuk proses pembentukan masa tulang adalah 
kalsium (Lesli, 1999). Sumber kalsium yang baik dengan avalailabilitas tinggi adalah produk susu seperti keju, mntega, dan yogurt (Lesli, 1999; Drewnowski, 2015).

Dengan maksud untuk menjaga penampilan, seringkali mahasiswi membatasi asupan gizinya, misalnya dengan menghindari makanan yang tinggi energi, seperti susu dan produk olahannya (Ueno, 2005). Disisi lain, dengan meningkatnya industri makanan dan minuman menyebabkan banyak produk yang beredar di masyarakat, seperti minuman berpemanis bersoda dengan harga yang murah dan rasa yang menyegarkan. Hal ini menyebabkan mahasiswa lebih memilih minuman tersebut dibanding minuman yang sehat seperti produk susu.

Mahasiswi gizi merupakan mahasiswi yang mempunyai pengetahuan yang baik tentang pentingnya kalsium bagi tubuh dan sumber kalsium, diharapkan mempunyai perilaku yang baik. Dengan latar belakang tersebut diperlukan penelitian untuk mengetahui konsumsi produk susu pada mahasiswi gizi sebagai upaya pemenuhan kebutuhan kalsium. Tujuan penelitian ini adalah untuk mengetahui jumlah dan kecukupan asupan kalsium serta kontribusi asupan produk susu terhadap asupan kalsium pada mahasiswi.

\section{METODE}

\section{Desain, Tempat dan waktu}

Penelitian ini menggunakan data sekunder dengan desain studi cross sectional. Lokasi penelitian adalah di Kampus Baru Depok Jawa Barat. Sampel adalah mahasiswi program studi gizi, Fakultas Kesehatan Masyarakat Universitas Indonesia angkatan 2014 (tahun ketiga) dan 2015 (tahun keempat) yang berjumlah 54 orang, yang dipilih secara random

\section{Jumlah dan cara pengambilan subjek}

Pemilihan angkatan 2014 dan 2015 dengan pertimbangan mahasiswi tersebut telah mengikuti mata kuliah khusus gizi seperti Ilmu Gizi Dasar dan Pemantauan Status Gizi, sehingga terampil dalam mengisi semiquantitative $F F Q$ (Food Frequency Questionaire). Data asupan dikumpulkan dengan menggunakan semiquantitative $F F Q$ yang telah divalidasi khusus mengukur asupan kalsium. Pada semiquantitative $F F Q$ terdapat 53 daftar bahan makanan sumber kalsium berdasarkan Daftar Kandungan Bahan Makanan (DKBM) tahun 2010, baik nabati, hewani, maupun makanan kemasan dari pabrik. Terdapat empat (4) pilihan jawaban terkait dengan frekuensi 
konsumsi yaitu tidak pernah, frekuensi dalam harian, mingguan dan bulanan. Selain daftar makanan sumber kalsium, pada semiquantitative FFQ terdapat keterangan porsi yang harus diisi oleh responden untuk mendapatkan jumlah makanan yang dikonsumsi. Untuk makanan kemasan responden diminta menyebutkan varian rasa, porsi, dan merek dagang. Dari hasil semiquantitative FFQ didapatkan asupan kalsium per responden dalam satu hari.

\section{Analisis data}

Analisis data menggunakan program pengolah data. Data ditampilkan secara deskriptif untuk mengetahui asupan kalsium secara umum, dibandingkan dengan Angka Kecukupan Gizi (AKG) (untuk kalsium) dan asupan kalsium dari berbagai makanan sumber kalsium termasuk suplemen. Untuk mengetahui hubungan asupan produk susu dengan asupan kalsium digunakan uji statistik Mann Whitney U karena data tidak terdistribusi normal. Untuk melihat hubungan antara jumlah kelompok sumber produk susu yang dikonsumsi dengan asupan kalsium digunakan spearman rank test.

\section{HASIL DAN PEMBAHASAN}

Rata-rata asupan kalsium

mahasiswi yang bersumber dari makanan sebesar 630 $4395 \mathrm{mg} /$ hari. Angka ini memenuhi $57,3 \%$ dari AKG untuk kalsium yang besarnya $1100 \mathrm{mg} / \mathrm{hari}$ untuk kelompok umur 19-29 tahun (Kemenkes, 2013). Sebagian besar mahasiswi yaitu $87 \%$ mempunyai asupan kalsium dibawah AKG dan hanya 13\% yang dapat mencapai AKG (Gambar 1). Jika dilihat dari reta-rata asupan kalsium, hasil penelitian ini lebih tinggi dibandingkan dengan penelitian pada mahasiswi keperawatan usia 19-23 tahun di Jepang yag hanya mencapai 380 \pm 209 mg/hari (Ueno, 2005). Hasil yang lebih rendah pada penelitan tersebut dipengaruhi oleh pengumpulan data asupan kalsium menggunakan duplicate portion sampling method yang hanya dilakukan pada hari biasa atau weekday, tanpa pengukuran di hari libur atau holiday yang memiliki potensi asupan kalsium yang lebih banyak, sehingga nilai tersebut kurang menggambarkan asupan kalsium responden. Selain itu, duplicate portion method memiliki beban yang cukup berat pada responden, sehingga terdapat kemungkinan perubahan asupan responden saat menduplikasi asupan makanannya. Sedangkan semiquantitative FFQ yang digunakan dalam penelitian ini tidak menyebabkan perubahan kebiasaan makan (Gibson, 2005). 
Gambar 1. Asupan Kalsium Mahasiswa berdasarkan AKG

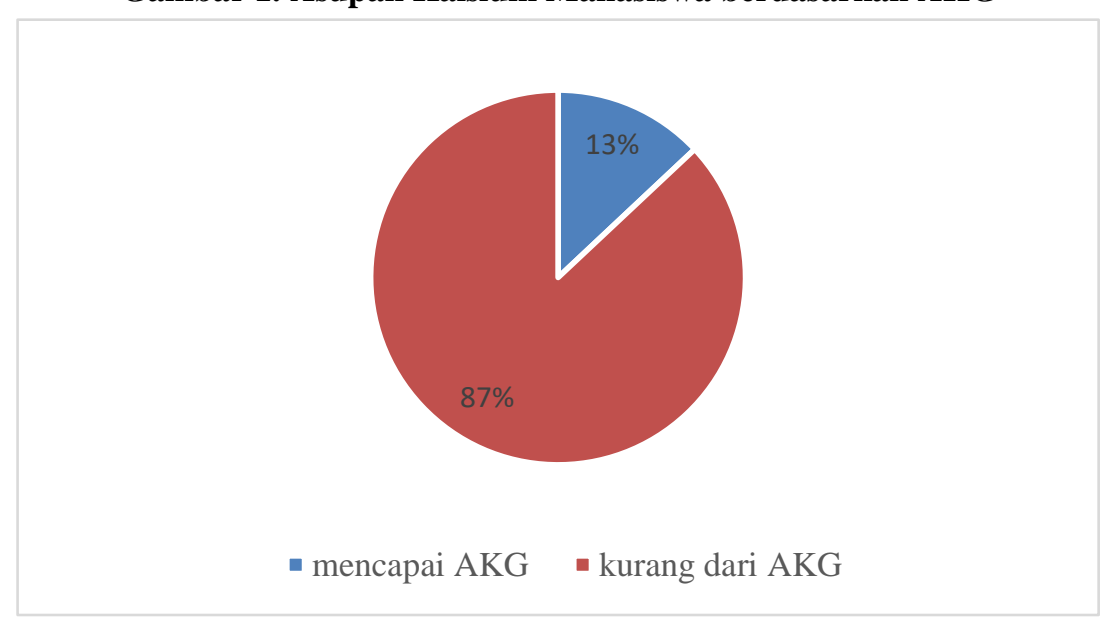

Hasil rerata asupan kalsium yang lebih rendah juga ditunjukkan oleh penelitian di Turki dengan sampel berumur 18 hingga 22 tahun. Penelitian di Turki mendapatkan hasil yang lebih rendah di setiap tingkat sosial ekonomi, dengan rerata asupan kalsium sebesar $144,84 \mathrm{mg} / \mathrm{hari}$ pada sosial ekonomi rendah, dan 212,93 $\mathrm{mg} /$ hari pada sosial ekonomi yang tinggi (Ersoy, 2018). Lebih rendahnya asupan kalsium di Turki tersebut karena perbedaan latar belakang pendidikan responden.

Sementara hasil penelitian pada mahasiswi kedokteran berumur 18-30 tahun di Iran mendapatkan nilai rerata yang lebih tinggi yaitu 1132,21 mg/hari (Bank, 2013), kemungkinan karena kisaran umur responden yang berbeda. Pada penelitian di Iran tersebut, umur responden meliputi umur responden yang lebih tua dengan kisaran umur responden
18 hingga 30 tahun, sementara penelitian ini hanya meliputi umur muda yaitu 19 hingga 23 tahun. Pada umur yang lebih muda cenderung terjadi perilaku makan yang tidak baik seperti pembatasan makan, menghilangkan waktu makan (skipping meal), jam makan tidak teratur yang menyebabkan asupan zat gizi menjadi sedikit termasuk kalsium (Ueno, 2010). Kemungkinan lain karena penelitian di Iran mempunyai angka gizi lebih dan obesitas yang lebih tinggi (20\%). Gizi lebih dan obesitas menunjukkan banyaknya asupan yang tinggi baik zat gizi makro yang mungkin juga asupan kalsium, dan sebagian besar sumber kalsium adalah susu dan hasil produknya yang banyak mengandung energi.

Pada umumnya orang Amerika Utara dan Eropa mempunyai asupan kalsium yang lebih tinggi dibandingkan 
orang Asia (Ueno, 2005). Hasil survey berbasis internet pada 1.730 mahasiswa di Amerika menunjukkan median asupan kalsium yang lebih tinggi yaitu sebesar 928,6mg/hari. Namun terdapat 78,5\% asupan kalsium masih dibawah AKG untuk 18 tahun dan 60\% asupan kalsium kurang dari AKG untuk 19 tahun. Perbedaan hasil penelitian di Amerika tersebut dibandingkan dengan penelitian ini karena penelitian di Amerika melibatkan laki-laki disamping perempuan sebagai responden, sementara pada penelitian ini hanya perempuan saja. Diketahui bahwa laki-laki mempunyai asupan zat gizi termasuk kalsium yang lebih besar dibandingkan dengan perempuan. Dan hasil penelitian di Amerika tersebut menunjukkan bahwa laki-laki mempunyai asupan kalsium yang lebih besar secara bermakna dibandingkan perempuan (Rose, 2018).

Kalsium dibutuhkan untuk pembentukan masa tulang. Tulang merupakan jaringan yang aktif yang secara konstan terjadi pembentukan dan perombakan tulang. Pada masa pertumbuhan terdapat proses pembentukan tulang yang dominan dimana proses bentukan tulang yang lebih cepat dibandingkan dengan perombakan tulang. Proses ini terjadi hingga mencapai peak bone mass sekitar usia 20 hingga 30 tahun. Jika masa puncak tulang yang dicapai tinggi maka tulang akan tetap kuat di usia tua walaupun kehilangan masa tulang terjadi. Hal ini akan memperlambat proses osteoporosis dan mencegah patah tulang (Brown 2011; Smolin dan Grosvenor, 2010).

Berdasarkan Tabel 1 didapatkan bahwa produk susu banyak menyumbangkan asupan kalsium (417.8 mg/hari) dibandingkan non diary products dan suplemen $(320,5 \mathrm{mg} / \mathrm{hari})$. Semua mahasiswi mengkonsumsi produk susu sebagai sumber kalsium, sehingga tidak ada satupun mahasiswi yang pantang dengan produk susu. 
Tabel 1. Asupan Kalsium berdasarkan Jenis Makanan Sumber Kalsium pada Mahasiswi

\begin{tabular}{|c|c|c|c|c|c|}
\hline Sumber kalsium & $\begin{array}{c}\text { Rata- } \\
\text { rata } \\
\text { mg/hari }\end{array}$ & median & Simpang baku & Min-mak & $\mathrm{p}$ value \\
\hline Susu skim & 6.6 & 0 & 31.0 & $0.00-205$ & 0.457 \\
\hline Susu full cream & 44.8 & 22.34 & 130.3 & $0.00-883.6$ & 0.12 \\
\hline Susu UHT & 138.3 & 59.8 & 86.9 & $0.00-300$ & 0.602 \\
\hline Yogurt & 33.5 & 12.65 & 55.0 & $0.00-308.6$ & $0.004 * *$ \\
\hline Keju & 18.6 & 49.2 & 84.0 & $0.00-407$ & 0.14 \\
\hline Ice cream & 10.6 & 7.0 & 16.9 & $0.00-115$ & 0.302 \\
\hline Butter (mentega) & 0.24 & 0.00 & 0.73 & $0.00-5$ & 0.69 \\
\hline $\begin{array}{r}\text { Minuman susu } \\
\text { lainnya }\end{array}$ & 30.00 & 6.00 & 56.3 & $0.00-290$ & 0.927 \\
\hline Suplemen & 0.0 & 17.3 & 71.8 & $0.00-428$ & 0.90 \\
\hline Dairy product & 417.8 & 325.0 & 367.7 & $3.00-1.864$ & $0.000 * *$ \\
\hline Nondairy product & 320.5 & 373.0 & 244.2 & $72.0-1.308$ & \\
\hline Total kalsium* & 630.0 & 526.6 & 395 & $136-1.937$ & \\
\hline
\end{tabular}

Produk susu merupakan sumber kalsium yang baik. Produk susumerupakan sumber utama kalsium di Amerika dan Perancis (Drewnowski, 2015) juga di Indonesia. Dari produk susu dapat menyumbangkan 15\% AKG untuk kalsium per porsi atau sekitar 120 mg kalsium (Drewnowski, 2015; Lesli, 1999), sementara pada penelitian ini asupan produk susudapat menyumbangkan 39,98\% AKG untuk kalsium. Rerata asupan kalsium dari produk susu pada penelitian ini (417.8 $\mathrm{mg} / \mathrm{hari}$ ) tidak berbeda jauh dengan hasil penelitian Bank et al di Iran (444,25 $\mathrm{mg} / \mathrm{hari}$ ).

Pada penelitian ini menunjukkan adanya hubungan yang bermakna antara asupan produk susu dengan asupan kalsium $(\mathrm{p}=0.000)$. Hasil ini sejalan dengan hasil penelitian lainnya yang mendapatkan korelasi positif antara konsumsi susu dengan asupan kalsium (Rose, 2018;Vatanparast, 2006; Ueno, 2005).

Mahasiswi mempunyai kebiasaan mengkonsumsi beragam produk susu. Sebagian besar mengonsumsi 3 hingga 4 kelompok produk susu. Hanya satu orang yang mengonsumsi ke delapan kelompok produk susu (Tabel 2). Dengan menggunakan sperman rank correlation terdapat korelasi positif yang cukup erat secara bermakna antara jumlah kelompok produk susu dengan asupan kalsium $(\mathrm{r}=0.379$ dan $\mathrm{p}=0.003)$. Semakin banyak mengonsumsi makanan sumber kalsium maka akan semakin banyak konstribusi terhadap asupan kalsium. Hal ini didukung dengan hasil penelitian ini yang menunjukkan terdapat perbedaan yang bermakna antara jumlah kelompok 
produk susu yang dikonsumsi dengan asupan kalsium $(\mathrm{p}=0.018)$.

Pada produk susu selain kalsium, terkandung banyak zat gizi lainnya seperti protein magnesium, pospor, beberapa vitamin B, vitamin D (Douglas, 2010) dan tinggi energi (Drewnowski, 2015). Produk susu selain dapat mencegah osteoporosis, ternyata dapat menurunkan risiko diabetes tipe 2 (Shu,2017). Hasil penelitian di Spanyol menunjukkan konsumsi produk susu $\leq 14$ kali/minggu dapat meningkatkan risiko diabetes melitus tipe 2 sebesar 1,27 kali (Ortega, 2013). Sementara hasil studi di Belanda mengonsumsi total produk susu $\geq 187,6$ gram/hari (atau setara dengan segelas susu) bersifat protektif terhadap diabetes melitus tipe 2 dibandingkan dengan mengonsumsi $\leq 87,5$ gram/hari (Eussen, 2016).

Tabel 2. Jumlah kelompok dairy product yang dikonsumsi mahasiswi dalam satu bulan

\begin{tabular}{ccc}
\hline Jumlah kelompok diary products & $\mathrm{n}$ & $\%$ \\
\hline 2 & 3 & 2.1 \\
3 & 22 & 15.7 \\
4 & 14 & 10.0 \\
5 & 6 & 4.3 \\
6 & 9 & 6.4 \\
7 & 3 & 2.1 \\
8 & 1 & 0.7 \\
\hline 58 & 58 & 100
\end{tabular}

Berdasarkan jenis kelompok produk susu, asupan kalsium terbanyak berasal dari susu UHT (138,3 mg/hari), susu fullcream (44,8 mg/hari), yogurt (33,5 mg/hari) dan paling sedikit berasal dari butter (mentega) (Tabel 1). Dengan menggunakan Mann Whitney $U$ test, terdapat hubungan yang bermakna antara asupan yogurt dengan asupan kalsium $(\mathrm{p}=0,004)$. Hasil penelitian ini didukung dengan hasil studi di Amerika yang menunjukkan bahwa mahasiswi berlatar belakang gizi dan kesehatan banyak mengkonsumsi susu, keju, dan yogurt sebagai sumber kalsium (Douglas, 2010). Hasil penelitian di Perancis menunjukkan bahwa susu cair dan yogurt mempunyai keuntungan sebagai sumber kalsium, karena indeks harga dan energi yang rendah, tetapi memenuhi kebutuhan kalsium, sementara keju memiliki energi yang tinggi dan harga yang tergolong mahal (Drewnowski, 2015). Kemungkinan, hal ini yang menjadikan mahasiswi gizi lebih memilih susu dan yogurt sebagai sumber kalsium, selain dari aspek kepraktisan. Sementara ini keju dikonsumsi dengan pelengkap 
lainnya (seperti roti), atau sebagai penambah rasa lezat pada snack pisang, kue, dan cake, yang tentunya hanya dalam jumlah sedikit, sehingga kontribusinya sebagai penyumbang kalsium juga kecil. Pemilihan yogurt sebagai sumber kalsium mungkin karena yogurt memiliki cita rasa yang khas sebagai produk hasil fermentasi. Yogurt merupakan makanan yang baik selain sebagai sumber kalsium juga bersifat protektif terhadap kejadian diabetes melitus tipe 2 yang dapat menurunkan risiko diabetes tipe 2 (Eussen, 2016).

Latar belakang pendidikan merupakan salah satu faktor mempengaruhi asupan zat gizi. Harapannya mahasiswi dengan latar belakang kesehatan termasuk gizi mempunyai pengetahuan yang mendalam dan luas, terkait dengan fungsi kalsium dan makanan sumber kalsium yang baik. Dengan pengetahuan yang baik dapat membentuk sikap dan perilaku yang baik pula sehingga pada akhirnya dapat meningkatkan asupan kalsium (Ueno, 2006; van der Kruk, 2014; Bank, 2013). Sejumlah 133 mahasiswi di salah satu institusi pendidikan gizi dan dietetik Belanda dilibatkan dalam suatu penelitian kohor untuk melihat adanya perubahan asupan zat gizi setelah menempuh pendidikan di institusi tersebut. Hasil penelitian menunjukkan terdapat peningkatan rerata asupan kalsium di tahun pertama dari $972 \mathrm{mg} /$ hari menjadi $1091 \mathrm{mg} / \mathrm{hari}$ di tahun keempat. Rerata asupan kalsium di tahun keempat lebih tinggi secara bermakna dibandingkan di tahun pertama dengan $\mathrm{p}=0,003$ (van der Kruk, 2014). Hasil ini menunjukan bahwa mahasiwi sangat berminat dengan makanan dan kebiasaan makan yang baik sehingga mengubah pengetahuan gizinya menjadi lebih baik selama kuliah. Penelitian lain yang mendukung telah dilakukan di Amerika yang membandingkan asupan kalsium pada mahasiswi gizi dengan mahasiswa bukan gizi, dengan total 314 orang berumur 1837 tahun. Hasil penelitian menunjukkan bahwa rerata asupan kalsium pada 2 kelompok mahasiswi gizi yaitu 1398 $\mathrm{mg} /$ hari dan $1273 \mathrm{mg} / \mathrm{hari}$, lebih tinggi dibandingkan 2 mahasiswa bukan gizi yang asupannya hanya $818 \mathrm{mg} / \mathrm{hari}$ dan 889 mg/hari. Pada 2 kelompok mahasiswi gizi asupan kalsiumnya mencapai $63 \%$ dan 57\% AKG lebih tinggi dibandingkan 2 kelompok mahasiswa bukan gizi yang hanya mencapai $24 \%$ dan $30 \%$ AKG (Douglas, 2010). Latar belakang gizi ini yang menyebabkan semua responden dalam penelitian ini mengkonsumsi produk susu dan dengan banyak variasi dan sumber, sehingga tidak satupun 
mahasiswi memantangnya., meskipun demikian berdasarkan kuantitas asupan kalsium masih rendah. Kemungkinan lain, produk susu sering dikonsumsi tetapi jumlahnya kurang. Dapat pula produk susu dikonsumsi tetapi hanya sebagai selingan dan tidak dikonsumsi sebagai bagian dari makan besar (meal). Banyaknya minuman kemasan produk susu yang dijual dalam ukuran kecil dan ekonomis (sesuai dengan daya beli mahasiswi), juga menjadi penyebab rendahnya asupan kalsium. Kemungkinan lainnya, mahasiswi lebih memilih minuman kemasan berpemanis dengan ukuran yang lebih besar tetapi harganya lebih murah, dan dengan rasa yang lebih lezat dan menyegarkan, dibandingkan

\section{SIMPULAN DAN SARAN}

Asupan kalsium pada mahasiswi gizi hanya mencapai $(630 \pm 395 \mathrm{mg} / \mathrm{hari})$ atau $57,37 \%$ dari kebutuhannya, dan hanya $13 \%$ mahasiswa yang mengonsumsi kalsium sesuai dengan Angka Kecukupan Gizi (AKG). Terdapat hubungan antara asupan produk susu dengan asupan kalsium. Untuk mencegah osteoporosis di kemudian hari, maka perlu upaya diberikannya KIE sebagai upaya pengingat kembali pentingnya asupan kalsium yang cukup dan sumber dengan produk susu yang harganya relatif mahal.

Masa mahasiswi adalah masa kritis terhadap proses pencapaian peak bone mass karena pada masa ini masih terjadi proses pembentukan massa dan kekerasan tulang, namun karena suatu hal menyebabkan asupan kalsium rendah. Untuk itu perlu upaya pesan KIE (KIE dipanjangkan dulu, kemudian disingkat) sebagai reminder pentingnya asupan kalsium yang cukup dan dengan sumber kalsium yang baik. Perlunya pihak kampus untuk menyediakan makanan sumber kalsium dengan harga yang murah melalui penyediaan vending machine dan membuat kebijakan terkait penyediaan makanan sumber kalsium di kantin.

kalsium yang baik pada mahasiwi gizi. Bila memungkinkan, kepada pihak berwenang di kampus perlu menyediakan makanan sumber kalsium dengan harga yang murah melalui penyediaan vending machine dan membuat kebijakan terkait penyediaan makanan sumber kalsium di kantin. Perlu dilakukan penelitian lanjutan untuk melihat faktor yang berkontribusi (avalilability, accessibility, convenience, dan cost) terhadap asupan kalsium sehingga dapat dilakukan pendekatan untuk meningkatkan asupan kalsium pada mahasiswi. 


\section{DAFTAR PUSTAKA}

Bank,S.S.,Ghanjali,N.,Ghalaeh,R, Seyyed.,A.,Leila. 2013. Association between dairy and calcium intake and general and central obesity among female students. Journal of Education and Health Promotion ;2(16):1-6.Doi10.4103/22779531.112685

Brouwer-Brolsma, Sluik,D., Singh-Povel,C.M., Feskens,E.J.M. 2018 Dairy Product consumption is associated with prediabetes and newly diagnosed type 2 diabetes in the Lifetimes Cohort Study. British Journal of Nutrition,119:442-455

Brouwer-Brolsma EM, Sluik D, Singh-Povel CM, Feskens EJM. 2018. Dairy product consumption is associated with prediabetes and newly diagnosed type 2 diabetes in the Lifelines Cohort Study. British Journal of Nutrition 119: 442-55.

Brown, J.E. Nutrition through the Life Cicle, Fluoride. Doi:10.1039/9781847559463

Douglas,C.C.,Rumbak,I.,Baric,I..C.,Kovacina,M., Piasek,M..,Illich,J.Z. 2010. Are new generations of female college-student populations meeting calsium requirements: comparison of American and Croatian female students. Nutrients. 2599-610. doi:10.3390/nu2060599

Drewnowski,A.,Tang,W.,Brazeilles,R.2015. Calsium requirements from dairy foods in France can be met at low energy and monetary cost. The British Journal of Nutrition,114(11):1920-1928.

Ersoy,B.,Kizilay,D.O.,Yilmaz,S.K.,Taneli,F., and Gumuser,G. 2018.Bone mineral density, vitamin $d$ status, and calcium intake in healthy female university students from different socioeconomic groups in Turkey. Archives of Osteoporosis. 13:135.Doi:10.1007/s11657018-0482-1

Eussen,S.J.P.,Van Dongen,M.C.J., Wijckmans,N., den Biggelaar,L., Oude Elferink,S.J.W.H., Singh- Povel,C.M., Schram,M.T., Sep,S.J.S., Van der Kallen,C.J., Koster,A., Schaper,N., Henry,R.M.A., Stehouwer,C.D.A., and Dagnelie,P.C.2016. Consumption of dairy food in relation to impaired glucose metabolim and Type 2 diabetes mellitus:
J.Gipas, Mei 2019, Volume 3 Nomor 1

ISSN 2599-0152 eISSN 2599-2465

http://jos.unsoed.ac.id/index.php/jgps

the Maastricht study. Britis Journal of Nutrition, 115:1453-1461

Ford,M.A.,Bass,M.A.,Keathley,R.2007.

Osteoporosis Knowledge and Attitudes: A Cross-Sectional Study Among CollegeAge Student. Journal of American College Health.56(1):43-50

Gibson,R.S. 2005. Principle of Nutritional Assessment. New York. Oxford University Press.

Kemenkes RI. 2013.Angka Kecukupan Gizi yang Dianjurkan Bagi Bangsa Indonesia Nomor 75 Tahun 2013. Jakarta:Kemenkes

Larson,N.L.,NeumarkSztainer,D.,Harnack,L.,Wal 1,M.,Story,M.,Eisenberg,M.E. 2009. Calsium and dairy intake:longtudinal trendsduringthe transition to young adulthood and correlates of calcium. Journal of Nutrition Education and Behavior.41(4):254-260

Leslie,M.,Richard,W.S.1999. Osteoporosis: implications for risk reduction in the collegesetting.Journal Of American College Health. 48 (2):67-71

Ortega,E., Franch,J., Castell,C., Goday,A., RibasBarba,L., Soriguer,F., Vendrell,J., Casamitjana,R., Bosch-Comas,A., Bordiu,E., Calle-Pascual,A., Carmena,R., Castano,L., Catala,M., Delgado,E., Gaztambide,S., Girbes,J., Lopez-Alba,A., Martinez-Larrad,M.T., Menendez,E., MoraPeces,I., Pascual-Manich,G., RojoMartinez,G., Serrano_Rios,M., Urrutia,I., Valdes,S., Vazquez,J.A., Go,is,R.,.2013. Mediterranean Diet Adherence in Individuals with Prediabetes and Unknown Diabetes: The Di@ betet.es study. Annuals of Nutrition \& Metabolism,62:339-346

Persagi. 2010. Daftar Komposisi Bahan Makanan. Jakarta:Gramedia.

Rose,A.M.,Williams,R.A,Kennel,J.A and Gunther,C. 2018. Determining attitudinal and behavioural factors concerning milk and dairy intake and their association with calsium intake in college student. Nutrition Research and Practice.12(2):142-148

Rose,AM.,Williams, R.A.,Hanks,A.S.,Kennel,J.A., a nd Gunther,C. 2017. Milk vending does not improve college students' milk and calcium intakes. Health Promotion Practice.2017,20 (10): $1-8$ 
Shu,P.S., Chan,Y.M., Huang,S.L. 2017. Higher body mass index and lower intake of dairy products predict poor glycemic control among Type 2 Diabetes patients in Malaysia. PLOSone 12(2):1-16 http://dx.doi.org/10.1371/journal.pone.017 $\underline{2231}$

Smolin,L.A and Grosvenor,M. 2011. Healthy Eating: A Guide to Nutrition.Second Edition.New York: Chelsea House Publishers.

Spronk,I.,Kullen,C..,Burdon,C.,O’Connor,H. Relationship between nutrition knowledge and dietary intake. The British Journal of Nutrition.111(10):1713-1726.

Ueno,K.,Nakamura,K.,Saito,T.,Okuda,Y., and Yamamoto,M.2005. Intakes of calcium and other nutrients related to bone health in Japanese Female College Students: a study using the duplicate portion sampling
J.Gipas, Mei 2019, Volume 3 Nomor 1

ISSN 2599-0152 eISSN 2599-2465

http://jos.unsoed.ac.id/index.php/jgps

method.Tohoku Journal Experimental Medicine,(206):319-326.

Van der Kruk,J.J., Jager-Witternaar,H., and van der Schans, C.P. 2014. Do Dutch nutrition and dietetics students meet nutritional requirements during education. Public Health Nutrition, 17 (6): 1237-1244

Vatanparast, H., Lo Elisabeth., Henry, C. J., Whiting, S.J. 2006. A Negative Trend in Calcium Intake was Accompanied by a Substitution of Milk by Noncarbonated Soft Drinks in Canadian Female Students. Nutrition Research,.26 (2006) : 325-329

Wlodarek,D., Glabska,D., Lange,E.2014.The Effect of Dairy Products Choice on Calcium Dietary Intake in Female University Students of Nutritional Faculty. Rocz Panstw Zakl Hig,(1); 35 